\title{
Learning Single Stance Pencak Silat through Computer Based Training (CBT)
}

\author{
Iis Marwan ${ }^{1}$ \\ ${ }^{1}$ Universitas Siliwangi, Indonesia \\ Correspondence: Iis Marwan, Universitas Siliwangi, (UNSIL) Tasikmalaya, Indonesia. E-mail: \\ marwaniis@yahoo.co.id
}

Received: January 16, 2014

Accepted: February 20, 2014 Online Published: February 28, 2014

doi:10.5539/ass.v10n5p35

URL: http://dx.doi.org/10.5539/ass.v10n5p35

\begin{abstract}
The purpose of this research is to improve the learning outcomes of a single stance of pencak silat by applying methods of computer based training (CBT) courses to students of Physical Education, Health and Recreation Faculty of Teacher Training and Education, Universitas Siliwangi. This is an action research involving 67 students who were enrolled in pencak silat course. Techniques of data collection consisted of tests and observations. Several tests were used to obtain data about the single stance of pencak silat skills. Observations used to collect data were related to learning activities involving students and faculty, especially at the time of application of learning tools (computers, cameras, and LCD). The results of this study concluded that the application of learning tools (i.e. computers, cameras, and LCD) are very effective to improve students' skills of pencak silat to master single stance with a level of effectiveness: (1) First cycle increases by $45.8 \%$ with a mean value of 79.6, and (2) Cycle II increases by $27.4 \%$ with an average of $88.73 \%$. This study concludes that the method of computer based training (CBT) was effectively used to improve students' learning outcomes of a single stance in the pencak silat.
\end{abstract}

Keywords: learning, computer based training methods, a single stance of pencak silat

\section{Introduction}

Pencak Silat is a compound word. Pencak and Silat has the same meaning and is part of the culture of the indigenous peoples of Southeast Asian ethnic groups who are native of the countries in the area of Brunei Darussalam, the Philippines, Indonesia, Cambodia, Laos, Malaysia, Myanmar, Singapore, Thailand and Vietnam.

The word Pencak is commonly used by the people of Java, Madura and Bali, while Silat is commonly used by people in other parts of Indonesia, Malaysia, Singapore, Brunei Darussalam and Thailand (Southern) and the Philippines. The Malay population is among hundreds of ethnic groups inhabiting the region (Maryono, 2000). Pencak silat is the essence of self-defense and cannot be used for showing off (Maryono, 2000). Silat is a martial-attacking movement closely associated with spiritual, so it can turn on instinct, drive the human conscience and submit to God Almighty. As stated by Monoarfa (2005), Pencak is a game (skill) to defend themselves with parry skill. Pencak silat has values or aspects:

a. The art of Pencak Silat is a whole branch of engineering of movement; it is a modification of the technique of self-defense, and moves in accordance with the rules of aesthetics, and its use is intended to showcase the beauty of pencak silat;

b. Mental Spiritual Pencak Silat is a branch of modified pencak silat techniques and movement and its use is intended to illustrate and also inculcate the teachings of the philosophy of pencak silat;

c. Pencak Silat Sports is a modification of technique and stance of pencak silat moves, and its use is aimed at creating and maintaining physical fitness and agility and sports performance;

d. In Pencak Silat, the whole purpose of using specific techniques and movement in order to maintain or defend oneselves.

Pencak Silat is divided into two categories, the sparring and art categories. Art category is furtherdivided into three types namely Single, Dual, and Team. Pencak silat is included as a sport competed at the school level activities in Indonesia. Apart from being one of the games in sports competition, in order to preserve pencak silat 
as a sport, the native of Indonesia in school often do pencak silat performances.

Pencak Silat in Health, Physical Education and Recreation courses at Faculty of Teacher Training and Education Universitas Siliwangi is included as a compulsory 2 (two) credits subject. Given the amount of material that must be learned by the students with a very limited time, then the question of how can pencak silat course be learned effectively (practice) mainly if material shown cannot be repeated. In the process of learning the Researchers feel inconvenient because every element of the motion must be repeated several times, and this can be quite exhausting. Advancement of learning tools is rapid, especially with the use of computers. Utilization of such tools needs to be done to make the learning process effective and efficient. So is the use of motion for the learning process, the role of computer tools can be appropriately used. By using computers, motion analysis can be utilized, the students can repeatedly observe movement that was done, so they can improved on any elements of the movement that they perceived as lacking.

eLearning is a very popular computer-based training method. eLearning training courses can be very basic PowerPoint slides or be very elaborate, containing music, graphics and audio narration. eLearning courses are broken down into modules that contain the training content. Graphics and images enhance the learning by providing a visual component. Audio narration, which can be recorded in a studio or even directly into your computer through specific programs, can be added to the content and help learners retain information. eLearning modules can have quizzes and tests that accompany the content so learner progress can be tracked. Workbooks can also be created to accompany the training so the student can follow along or review the training content at a later time. http://www.ehow.com/way_5241020_computer-based-training-methods.html\#ixzz2cpwuk2Oe

To overcome the difficulty of learning a single stance pencak silat, the author tries to use computer based training methods. Method of Computer Based Training (CBT) is a method where the process of learning or training to use computer tools that can display live motion technique, in the process, student or athlete learn the techniques of motion based on impressions of the computer, then do the technique of motion to be recorded and compared with that shown in the computer.

Based on the background of the problems that have been described, the author of this research seeks to answer the following research problem: "Does learning the single stance pencak silat through CBT improve students' skills?"

\section{Research Methodology}

The method used in this study is action research . Action research is a research the form of reflective actions taken by samples for rational steadiness of their actions in carrying out the task, and deepen understanding of the actions that he did, or a form of self-reflection study conducted by partisans in social situations (including education) to improve the rationality and truth (Carr \& Kemmis, 1996 in Hardjodipuro, 1997). This study is also participatory and collaborative assessment process is carried out in the form of cycle (cyclical) which consists of 4 phases: 1) plan, 2) take action, 3) observing, and 4) reflection.

One characteristic of Classroom Action Research is a cyclic or measurable steps and planned in a cycle so that the design of this research carried out in the form of the cycle model as proposed by Kemmis and Mc Taggart, (1992). The phases of the cycle are Planning, Acting, Observing and Reflecting. The same is stated by Suharsimi (2010) that in action research design panel consisting of the steps of planning, action, observation, and reflection.

The research was carried out at Universitas Siliwangi campus in Tasikmalaya, Indonesi. The research subjects are students taking the theory and practice of pencak silat course at the Physical Education, Health and Recreation Faculty of Teacher Training and Education Universitas Siliwangi. A total of 67 students consisting of 54 male and 13 female were chosen.

Data or information, which is used as the source for analytical purposes in order to solve the problem of this research, came from:

a. Result of discussions between researchers, observers and students.

b. Activity shown by all students during the learning process in action research.

The instrument in this study in accordance with the nature of the research model is the researcher herself who is the main instrument (Nasution, 1992), using a variety of data collection tools, among others, data on changes in the behavior of students during the learning takes place. To collect the data, the researcher uses the instrument: faculty and student activity sheets, field notes, interview notes and student worksheets.

The process of data collection is done through observation in the treatment process at every single moment of pencak silat classes via optimizing the utilization of computer, camera, and LCD. In addition to the faculty 
researcher and assisted by two assistant professors, during observations, the researcher is also assisted by peers (research partner) during the lecture.

The steps taken in data processing of the research include: 1) data collection phase and categories of data, 2) Phase of data validation through triangulation (Hopkins, 1985), and the next step 3) Phase of interpretation of data collected after going through these stages.

Data are grouped into three parts, namely: 1) the data obtained from analysis of the data sheet perform single stance pencak silat moves as indicators of mastery of skills (psychomotor) and group data obtained from student responses to understanding of single stance moving pencak silat through observation sheet / interview field notes as indicators of cognition, as well as the observation for affective variables. Furthermore, the data is processed using mean or average score to know the progress at each cycle.

\subsection{Activities in Each Cycle}

\subsubsection{Planning Actions}

Planning actions were carried out by preparing lesson plans for a variety of single-stance pencak silat moves, attendance list, computer software, digital camera, LCD (projector) and recording a single stance as the movement master, and guidelines for observating and judging form for a single stance move.

\subsubsection{Implementation Action}

During the activities of each cycle of learning activities that went according to plan where researchers, students and observers may be present $100 \%$ suggesting that the activities can affect the results of the study, therefore students can be motivated to cooperate in following the lectures so that the learning process can be said to be maximal.

\subsubsection{Observation Action}

Observations carried out using the assignment have been made, the implementation steps were used as the observation sheet. Lecturer observes students' activity during the lecture and when students complete, a reflection session with the lecturer is conducted. The thing that needs to be observed are positive activity of the students that include: The presence of students; Students who are actively working on the movement task; Students are diligently discussing; Students who actively ask, and Students who complete the movement tasks rapidly.

In addition to learning activities, teachers also pay more attention to students. In order to overcome the learning difficulties, lecturers must foster students' interest in learning and increase interest in learning by themselves.

Observations were conducted in accordance with the format that is set up and note down all the necessary things that occurred during the implementation process. The results of the action were assessed in accordance with the format that has been developed.

\subsubsection{Reflection Outcome Action}

Reflections of each cycle as material to improve the performance of the next cycle:

1) To evaluate actions taken include evaluation of quality, quantity and timing of any kind of action.

2) Conduct a meeting to discuss the results of evaluation of learning scenarios and student worksheets.

3) Improving the implementation of appropriate measures of evaluation results, to be used in the next cycle.

\section{Results}

\subsection{Analysis of Pre Cycle Data}

Pre-cycle data is the baseline data of capabilities of students without any prior action. This is the initial ability of the students in single stance mastery of pencak silat and is shown in Figure 1. 


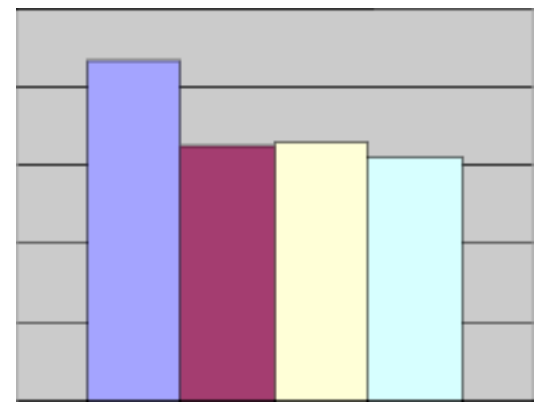

$\square$ KKM

$\square$ Cognitive

$\square$ Affective

$\square$ Psychomotor

Figure 1. Baseline data of students ability

Figure 1 shows the baseline data of students' ability with an overall mean score 65 (cognitive), the affective mean score $=66$, and the psychomotor mean score of 62. This cycle describes the initial conditions associated with the ability of student mastery of pencak silat single stance with an overall mean of 64.33 which is categorized as average ability, so it is necessary to apply the method of conditioning with computer based training (CBT).

\subsection{Analysis of Data for Cycle 1}

The first cycle data are capabilities of students after the first act. Data resulting from the first cycle about the ability of students to master the skills of a single stance pencak silat is shown in Figure 2.

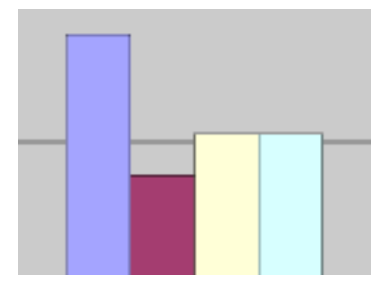

\section{$\square$ KKM}

$\square$ Cognitive

$\square$ Affective

$\square$ Psychomotor

Figure 2. Ability of learning single stance Pencak Silat in cycle I

Comparing with Figure I, data in Figure 2 shows that there is an increase in the ability to perform single stance pencak silat movement after Cycle 1 . This means that the ability of the learning outcomes of students showed improvement in cognitive mean $=7.6(12.6 \%)$, affective mean $=80.6(14.6 \%)$, and psychomotor mean $=80.6$ $(18.6 \%)$. The mean for overall learning outcomes of a single stance pencak silat in the first cycle shows there has been an increase in students' learning outcomes due to the implementation of computer-based training, amounting to 79.6 or $45.8 \%$. However, learning outcomes in general are still categorized as average. Recommendation of the results for this reflection is necessary for further actions in Cycle 2. 


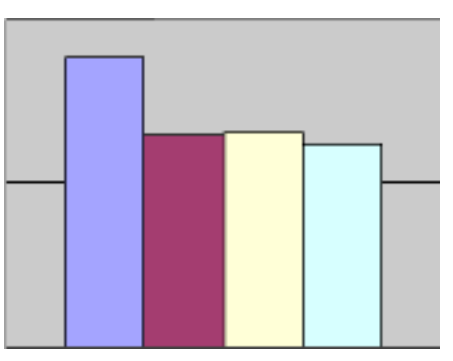

\section{$\square$ KKM \\ $\square$ Cognitive \\ $\square$ Affective \\ $\square$ Psychomotor}

Figure 3. Mean of improved learning outcomes for single stance Pencak Silat in cycle I

\subsection{Analysis of Data for Cycle 2}

Criteria for success on the theory and practice of pencak silat lecture, including mastery of a single movement as determined before the action has been set at $87 \%$ (Categories A value / weight 4). The mean learning outcomes in the first cycle have yet to describe the expected success rate; therefore it is necessary for the improvement actions in 2 cycles. The mean results of a single stance pencak silat moves in cycle 2 can be seen in Figure 4.

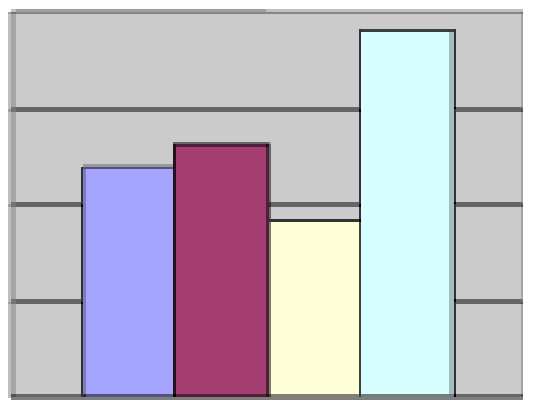

\section{$\square \mathrm{KKM}$ \\ $\square$ Cognitive \\ $\square$ Affective \\ $\square$ Psychomotor}

Figure 4. Average of learning single stance Pencak Silat in cycle 2

Based on the results from Figure 4, average learning for single stance pencak silat moves in cycles 2 shows a good improvement in cognitive mean $=88.1(10.5 \%)$ and psychomotor mean $=94(13.4 \%)$, but average for affective mean 84.1 (3.5\%).

The mean increase in learning outcomes for single stance pencak silat increased to very good. The rate of increase in learning outcomes can be seen in Figure 5.

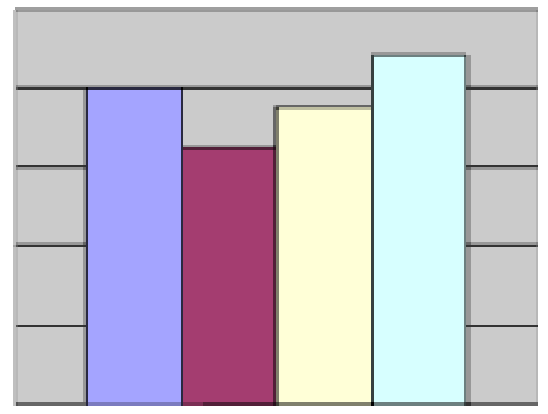

\begin{tabular}{|l|}
\hline$\square$ KKM \\
$\square$ Pre-cycle \\
$\square$ Cycle 1 \\
$\square$ Cycle 2 \\
\hline
\end{tabular}

Figure 5. Improvement in learning outcomes for single stance Pencak Silat in cycle 2 
Figure 5 illustrates the average increase in learning outcomes for single stance of pencak silat students from the cognitive, affective and psychomotor domains. Improved learning outcomes in cycle 2 showed an increase in student results is highly significant in all domains of learning.

There is a quite good improvement on cognitive with mean $=10.5 \%$, the average increase in the affective domain is by $3.5 \%$, while the highest increase is in the psychomotor domain which is $13.4 \%$. Since the improvement in learning single stance pencak silat movement has already exceeded the target achievement set by the researcher, two cycles of this study is regarded as sufficient.

Achievement of learning outcomes by applying computer based training (CBT) gained a score of 88.73 which is categorized as very good.

Observations of student activities from cycle to cycle is shown in Table 1.

Table 1 . Student activity data related to learning

\begin{tabular}{|c|c|c|c|c|c|}
\hline \multirow{3}{*}{ No } & \multirow{3}{*}{ Indicators } & \multicolumn{4}{|c|}{ Achievement } \\
\hline & & \multicolumn{2}{|c|}{ Cycle I } & \multicolumn{2}{|c|}{ Cycle II } \\
\hline & & $\sum$ & $\%$ & $\sum$ & $\%$ \\
\hline \multirow[t]{2}{*}{1} & Cognitive Domain & & & & \\
\hline & $\begin{array}{l}\text { The ability of students to know and understand the techniques of single stance } \\
\text { pencak silat movement }\end{array}$ & 52 & $77.6 \%$ & 59 & $88.1 \%$ \\
\hline \multirow[t]{5}{*}{2} & Affective Domain & & & & \\
\hline & $\begin{array}{l}\text { Student interaction in the following single stance pencak silat movement in } \\
\text { groups }\end{array}$ & 53 & $79.1 \%$ & 56 & $83.6 \%$ \\
\hline & $\begin{array}{l}\text { Relationships with the students during learning activities of single stance } \\
\text { pencak silat }\end{array}$ & 54 & $80.6 \%$ & 57 & $85.1 \%$ \\
\hline & $\begin{array}{l}\text { Motivation and enthusiasm in participating during learning single stance } \\
\text { pencak silat movement (complete tasks independently or group work) }\end{array}$ & 55 & $82.1 \%$ & 58 & $86.6 \%$ \\
\hline & $\begin{array}{l}\text { Learning ability of students in a single stance pencak silat movement with } \\
\text { modified rules }\end{array}$ & 54 & $80.6 \%$ & 56 & $83.6 \%$ \\
\hline \multirow[t]{3}{*}{3} & Psychomotor Domain & & & & \\
\hline & $\begin{array}{l}\text { Students' skills in conducting technical aspects of single stance pencak silat } \\
\text { movement }\end{array}$ & 54 & $80.6 \%$ & 63 & $94.0 \%$ \\
\hline & Average & \multicolumn{2}{|c|}{$80.6 \%$} & \multicolumn{2}{|c|}{$84.1 \%$} \\
\hline
\end{tabular}

Based on Table 1, it seems that the students' activity is relevant to the activities of learning a single stance pencak silat moves in cycle 2 increase compared with the first cycle. Data on activities which is less related to student learning is shown in Table 2.

Table 2. Activity that is less related to students learning

\begin{tabular}{llcccc}
\hline & & \multicolumn{3}{c}{ Achievement } \\
No & \multicolumn{1}{c}{ Indicators } & \multicolumn{2}{c}{ Cycle I } & \multicolumn{2}{c}{ Cycle II } \\
& & $\sum$ & $\%$ & $\sum$ & $\%$ \\
\hline 1. & Lecturers do not pay attention to the explanation & 19 & $28.35 \%$ & 13 & $19 \%$ \\
2. & Chatting with friends & 21 & $31.34 \%$ & 12 & $17.9 \%$ \\
3. & Another task & 17 & $25.37 \%$ & 9 & $13.43 \%$ \\
& Average & \multicolumn{2}{c}{$28.36 \%$} & & $16.78 \%$ \\
\hline
\end{tabular}


Table 2 shows that the activities which is less related to students' learning has decreased in cycle 2 compared with cycle 1 .

Data on students' understanding of a single stance pencak silat moves and mastery learning from cycle 1 to cycle 2 is shown in Table 3.

Table 3. Student understanding of single stance Pencak Silat and completeness of student learning

\begin{tabular}{llcc}
\hline \multirow{2}{*}{ No } & \multicolumn{2}{c}{ Observation } & \multicolumn{2}{c}{ Achievement } \\
& & Cycle I & Cycle II \\
\hline 1. & The average value of a single stance pencak silat moves & $79.6 \%$ & $88.73 \%$ \\
2. & Students who completed the task & $77.61 \%$ & $94 \%$ \\
3. & Students who did not complete the task & $22.39 \%$ & $6 \%$ \\
\hline
\end{tabular}

Based on Table 3, the average value of overall mastery of a single stance pencak silat increased $9.13 \%$ from cycle 1 to cycle 2 , as well as the percentage of students who achieve mastery learning increased $16.39 \%$ from cycle 1 to cycle 2 .

The research data reveal that by using computer based training methods, students were very enthusiastic in carrying out a single stance pencak silat techniques.

\section{Discussion}

Computer Based Training is a training method which uses the computer, where the athlete or the student can observe the element of motion on the computer, record their own movement and then repeating and comparing it with the motion shown on the computer.

These results in reinforcement of learning which according to Singer (1980) is relatively a permanent change in behavior caused by past practice or experience in a given situation. According to Bigge (1982) and Singer (1980), learning is a lasting change in the lives of individuals and is not preceded by a birth or descendants. Furthermore Winkel (1996) describes learning as a mental activity that takes place in an active interaction with the environment, which results in changes in the knowledge, understanding, skills, attitudes and values. The change is relatively constant. The is further clarified by Djamarah (1999) that, learning is a process of individual effort made to obtain a new behavior change as a whole, as a result of the individual's own experience in the interaction with the environment.

Furthermore Lutan (1988) explains that, learning is a change in behavior as a result of the experience, not because of the influence of heredity or maturity. Expected changes, is attached or permanent. Hurlock (2002) explains, developmental learning is derived from practice and effort. Slameto (2010) agrees by stating that it is a business process that made a person obtain a new behavior change as a whole, as a result of his own experience in the interaction with the environment.

Learning is a deliberate process to obtain either change behavior or skills and increasing knowledge is relatively fixed or last a long time, as a result of individual experience in the interaction with the environment regarding the cognitive, affective and psychomotor.

The learning process of physical education or sport cannot be separated from movement or motor activity, because it was the process of motor skill learning. Schmidt (1991) suggested that motor learning is a process of improvement of motor coordination abilities, through the optimization of external factors and the requirement that aims to gain the skills, capabilities and particular behavior. Sugiyanto (1993) suggested that the study of motion is realized through responses of the muscle. To learn more about learning motor skills, the concepts of motor learning or the learning of motion should first be examined. Kiram (2000) cites some expert opinion as follows: Gagne and Briggs (1979) suggested that motor learning is a change in behavior or changes in skills that can last for a certain period and not from the growth process.

Learning motion is a set of processes associated with practice or experience leading to changes which is relatively permanent in one's ability to show that skilled movements. Johnson and Johnson (1991) stated that the approach to learning through experience aimed at preparing the cognitive structure, modify attitudes, and improve the skills of learner. 
Computer based training (CBT) is helpful in teaching learners to perform a series of tasks (motion task). Computer based learning as a teaching process can be performed directly to present materials in an interactive learning model to provide and control the learning environment for each individual student (Splittgerber and Stirzaker, 1984).

All computer based learning application for the computer have the aspect of individual, interactive, and learning (Steinberg, 1991). Furthermore Tailor (in Merrill, 1996) states that all computer applications in education can be classified as a tutor, tool or tutee. Computer-based training (CBT) is any program which uses the computer as a primary means of delivering content. using software products installed on the computer, through a company or educational internet, or via the internet as Web -based training.

\section{Conclusion}

Based on the findings of this research, it can be concluded that the application of computer based training methods in learning pencak silat moves can improve students' ability to master the technique of a single stance movement. Based on the findings and conclusions of the above, it is suggested that:

a. Learning pencak silat can use computer based training (CBT) as an alternative in the learning process.

b. Lecturers / teachers should use learning tool especially computer equipment to carry out the process of learning motor skills.

\section{References}

Arikunto, Suharsimi, Suhardjono, \& Supardi. (2010). Penelitian Tindakan Kelas. Jakarta, Bumi Aksara.

Bigge, M. L. (1982). Learning Theories for Teachers. New York: Harper \& Row.

Djamarah, S. B. (1999). Psikologi Belajar. Jakarta, Rineka Cipta.

Gagne, R. M., \& Briggs. (1979). Principles of Instruktional Design. New York. Holt Rinehart and Winston.

Hardjodipuro, S. (1997). Action Research Sintesis Teoritik. Jakarta: IKIP-Jakarta.

Hopkins, D. (1985). A Teachers Guide to Classroom Research. Philadelphia: Open University Press.

Hurlock, E. (2002). Psikologi Perkembangan (5th ed.). Jakarta: Erlangga Kelia.

Jonassen, D. H. (1991). Objectivism versus Contructivism: Do We Need a New Philosophical Paradigm? Educational Technology Research and Development, 39(3), 5-14. http://dx.doi.org/10.1007/BF02296434

Kemmis, \& Taggart, M. (1992). The Action Research Planner. Dekain University, Vic.

Kiram, Y. (2000). Metode Pembelajaran Keterampilan Motorik Dasar Bagi Anak Usia SDN 2 Jingkang. Jakarta, Pusat Kesegaran Jasmani, Depdiknas.

Lutan, R. (1988). Belajar Keterampilan Motorik: Pengantar Teori dan Metode. Jakarta, Depdikbud Dirjendikti P2LPTK.

Merrill et al. (1996). Computer in Education. Boston: Allyn and Bacon.

Nasution. (1992). Berbagai Pendekatan dalam Proses Belajar dan Mengajar. Jakarta: Bumi Aksara.

Oong, M. (2008). Pencak Silat Merentang Waktu. Yogyakarta: Benang Merah.

Schmidt, R. A. (1991). Motor Learning and Performance: Human Kinetic Application to Motor Skill and Movement Behaviors. New York: Macmillan Publishing Co. Inc.

Sidentop, D. (Ed.). (1994). Sport Education: Quality Physical Education through Positive Sport Experience. Champaign: Humen Kinetics.

Singer, R. N., \& Dick, W. (1980). Teaching Physical Education: A System Approach. Bostoon; Houghton Miflin Company.

Slameto. (2010). Belajar dan Faktor Yang Mempengaruhinya. Jakarta. Rineka Cipta.

Splittgerber, F. L., \& Stirzaker, N. A. (1984). Computer Technology for Administrative Information and Instructional Management in School Districts. Educational Technology, XXIV(2).

Steinberg, E. R. (1991). Computer-Assisted Instruction: A Synthesis of Theory, Practice, and Technology. New Jersey: Lawrence Erlbaum Associates.

Sudarsono, F. X. (2001). Apikasi Penelitian Tindakan Kelas. Jakarta. Pusat Antar Universitas Untuk Peningkatan dan Pengembangan Aktivitas Instruksional Dirjen Dikti Depdiknas. 
Sugiyanto. (1993). Pertumbuhan dan Perkembangan, Bahan Penataran Bulu Tangkis Tingkat Dasar Seluruh Indonesia. Jakarta PB PBSI.

Suharso. (2005). Teori dan Praktek Pencak Silat. Cetakan Pertama, Jakarta: Penerbit PT Indeks.

Winkel, J. S. (2007). Psikologi Pendidikan (Edisi Ke-Dua). Jakarta, Kencana Prenada Media Grup. Retrieved April 11, 2012, from http://www.ehow.com/way_5241020_computer-based-training- methods.html\#ixzz2

\section{Copyrights}

Copyright for this article is retained by the author(s), with first publication rights granted to the journal.

This is an open-access article distributed under the terms and conditions of the Creative Commons Attribution license (http://creativecommons.org/licenses/by/3.0/). 